\title{
Financial Performance Evaluation of Grid Enterprises Based on IPA Model -- Taking XX Power Supply Bureau as an Example
}

\author{
Junda Yang \\ Finance of International Business School, Jinan University, China \\ Yun Xia (Corresponding author)) \\ Finance of International Business School, Jinan University, China \\ E-mail: 13676097885@163.com
}

Kefang Zhang

Finance of International Business School, Jinan University, China

Liu Yang

Finance of International Business School, Jinan University, China

Zhongtao Zhang

Finance of International Business School, Jinan University, China

Received: Oct. 14, 2018

doi:10.5296/bms.v9i2.14035
Accepted: Nov. 1, 2018

Published: December 11, 2018

URL: https://doi.org/10.5296/bms.v9i2.14035

\section{Abstract}

Using the data collected from the internal employee questionnaire, this paper adopts IPA method to analyze the financial performance and operation status of XX power supply bureau 
with some financial data as indicators. In addition, this paper evaluates the financial operation performance of the electric power enterprise, and puts forward relevant suggestions for the asset problems of the enterprise, hoping to help the managers to accurately grasp the operating status of enterprises, optimize the allocation of resources, and improve the management efficiency, so as to provide a useful reference for power grid enterprises to establish financial delicacy management system.

Keywords: Electric power enterprise, Financial operation performance, IPA 


\section{Introduction}

For power grid industry, as a key industry of national public infrastructure, it has the characteristics of large investment scale, long investment recovery period and low investment efficiency. In order to meet the needs of economic and social development and people's living power consumption, China plans to invest about 500 billion yuan a year to build efficient and green first-class power grid enterprises during the 12th five-year plan period. At present, China's power grid enterprises are facing the fierce competition in the market, complex development environment and challenging opportunities. After the baptism of market competition, China's power grid enterprises will also become more mature and stronger. But the premise that realizes these, need the enterprise not only unceasingly strives for perfection, strengthens the enterprise advantageous item, but also must make great efforts to fill the short board, strives to change the weak item into the strong point. With the increasing scale of power grid investment, the financial management of foundation engineering is more and more important. It can be seen that establishing a set of financial delicacy management system is of great significance for standardizing the cost expenditure of infrastructure projects, realizing the whole process of financial standardization management, improving the efficiency of infrastructure finance management and reducing risks. How to establish a financial delicacy management system? This paper tries to use the IPA model and take the $\mathrm{XX}$ power supply bureau as an example to establish a set of systems suitable for financial enterprise financial evaluation and management from the perspective of financial performance evaluation, in order to help managers and decision-makers grasp the current situation of enterprise operations more quickly and accurately, optimize various resource allocations, improve management efficiency, and provide useful reference for power companies to establish financial delicacy management systems.

\section{Literature Review}

\subsection{Financial Operation Performance Evaluation of Power Grid Enterprises}

In recent years, academic studies on financial operation performance of grid enterprises are not rare, and the indicator system construction methods mainly include KPI evaluation theory, Balanced Score Card method, Economic Value Added theory (hereinafter referred to as EVA) and so on. The key performance evaluation theory refers to the rating method that sets the key performance indicators to reflect the individual's work achievements and evaluate their performance level accordingly. For example, Chen Shiqiang (2011) evaluated the performance of grid enterprises from 9 dimensions and 36 indicators, such as financial return, cost, and asset operation, and proposed a relatively perfect evaluation system for the weight of indicators. The balanced score card theory is oriented by strategic goals to establish a set of financial and non-financial evaluation indicators, including financial performance indicators, customer indicators, internal business process indicators and learning and growth performance indicators, so as to comprehensively, comprehensively and systematically evaluate the operation performance of enterprises. Lin Zhang (2011) adopted a balanced score card from four dimensions: financial indicators (sales of electricity, unit sales cost, etc.), 
internal process performance indicators (power supply growth rate, line loss rate, etc.), meeting customer demand performance indicators (degree of customer satisfaction, etc.), learning and growth indicators (technical input-output ratio, etc.) to evaluate the performance of grid companies, and also established a relatively complete grid enterprise performance evaluation system. EVA refers to the profit after tax net profit of the enterprise minus the total cost of capital including equity and debt. The core idea of EVA theory is that when the company's capital gain exceeds the total cost of the capital invested in the income, it can bring value to shareholders. In order to improve the performance level, enterprises should continuously reduce the cost of input capital and pursue the maximization of capital output. Zhao Hongmei (2008) took 10 listed power companies as samples and evaluated their business performance with EVA theory, which reflected the real situation of the company and accurately reflected the value created by the company for shareholders, and also helped investors to practice the value investment concept. Other scholars have established a comprehensive performance evaluation system for power companies from other perspectives. Liu Xiao (2011) analyzed the problems existing in the performance evaluation system of existing power grid enterprises from the evaluation indicators of safety, reliability, high quality and other tasks such as development and innovation tasks, safety production, power grid planning, and engineering construction. And he combined with the characteristics of the grid enterprises, proposed improvements. Tang Danni (2017) selected key indicators to measure the financial performance of power companies from the five dimensions of profitability, asset quality, debt risk, business growth and infrastructure project benefits. And selected financial and non-financial factors from seven dimensions, studied the influencing mechanism of the financial operation performance of power enterprises, and helped power grid enterprises better understand the financial operation. Therefore, the evaluation system of the power company's business performance is more scientific and complete.

\subsection{IPA Model}

There are many evaluation systems for the performance of power companies. This paper innovatively uses IPA models to construct performance evaluation methods for power companies. The IPA was first proposed by Martilla and James (1977) in the marketing journal. Since the early 1990s, IPA has been widely used in the service industry, covering applications such as degree of service satisfaction, product performance, regional attractiveness and macro tourism policy development (Hawes \& Rao,1985; Hsu et al.,1998; Go \& Zhang,1997; Evans \& Chon,1989). Domestic scholars have also innovated the application of IPA to curriculum evaluation (Zeng Dejiang \& Bao Zhongfu,2018) and the improvement measures of key performance of logistics enterprises (Jiang Peng \& Liu Guangdong,2018). IPA requires respondents to evaluate the various evaluation factors in terms of importance and performance of the metrics of the specified respondents. It builds four quadrants with the average importance and average performance of all indicators, and analyzes and interprets each metric by its importance and performance evaluation within these four quadrants. 
High

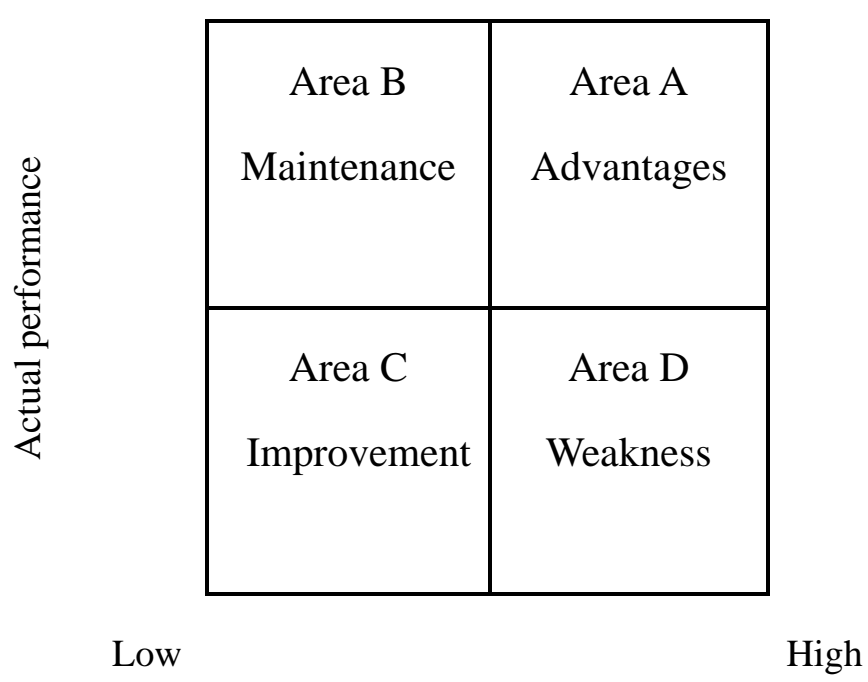

Importance

Figure 1. IPA analysis matrix diagram

IPA method is divided into four quadrants, area A is the advantage area, the importance of indicators and actual performance are higher, so the indicators in this area can be considered as dominant indicators. Area B is the maintenance area, the importance of indicators is relatively low, but the actual performance is higher, the indicators left in the region needed continue to maintain. Area $\mathrm{C}$ is the improvement area, the importance of indicators and actual performance are relatively low, the indicators in this area are improvement indicators. Area D is the weakness area, the importance of indicators is quite high, but the actual performance is not good, the indicators in this region need to be targeted improvement. Therefore, this paper innovatively uses the IPA model to evaluate the operating performance of power companies. It is expected to help power managers to accurately grasp the current state of business operations, optimize resource allocation, improve management efficiency, and provide useful reference for power companies to establish financial delicacy management systems.

\section{Research and Design of IPA Model}

\subsection{Selection Principles of Financial Performance Evaluation Indicators}

In terms of the selection of financial performance evaluation indicators of power grid companies, this paper believes that the selection of evaluation indicators should be based on the evaluation objective and objective reality, and the following principles should be followed.

(1) Scientific principle. The original intention of performance evaluation is to hope that the evaluation activities can be completed with the research results of various disciplines. 
(2) Operational principle. Ease of operation will improve the efficiency of our financial performance evaluation. The design of indicators should be operable, data should be easy to obtain, and the meaning of indicators should be specific and easy to calculate.

(3) Combine the subjective with the objective. Objective evaluation and subjective evaluation of various financial indicators have advantages and disadvantages. Therefore, in the process of selecting evaluation methods, the two categories of methods should be taken into account simultaneously. However, IPA analysis can precisely solve this problem. This paper regards importance evaluation as the subjective evaluation of financial indicators and actual performance as the objective evaluation of financial indicators.

(4) The principle of validity. The validity principle refers to that the selection of the indicator system needs to consider the characteristics of the research object and build it according to the specific situation of the research target. Only the established indicator evaluation system can truly reflect the financial performance of the power grid company studied in this study, then this indicator system is effective.

\subsection{Determination of Measurement Indicators}

According to the above selection principle, combined with the financial operation status of XX power supply bureau, this paper starts from the four dimensions of income, cost, assets and debt, and finds the key business activity indicators that will promote these four dimensions in the work of $\mathrm{xx}$ power supply bureaus. The indicators selected are as follows.

Table 1. Indicators affecting financial performance of XX power supply bureau

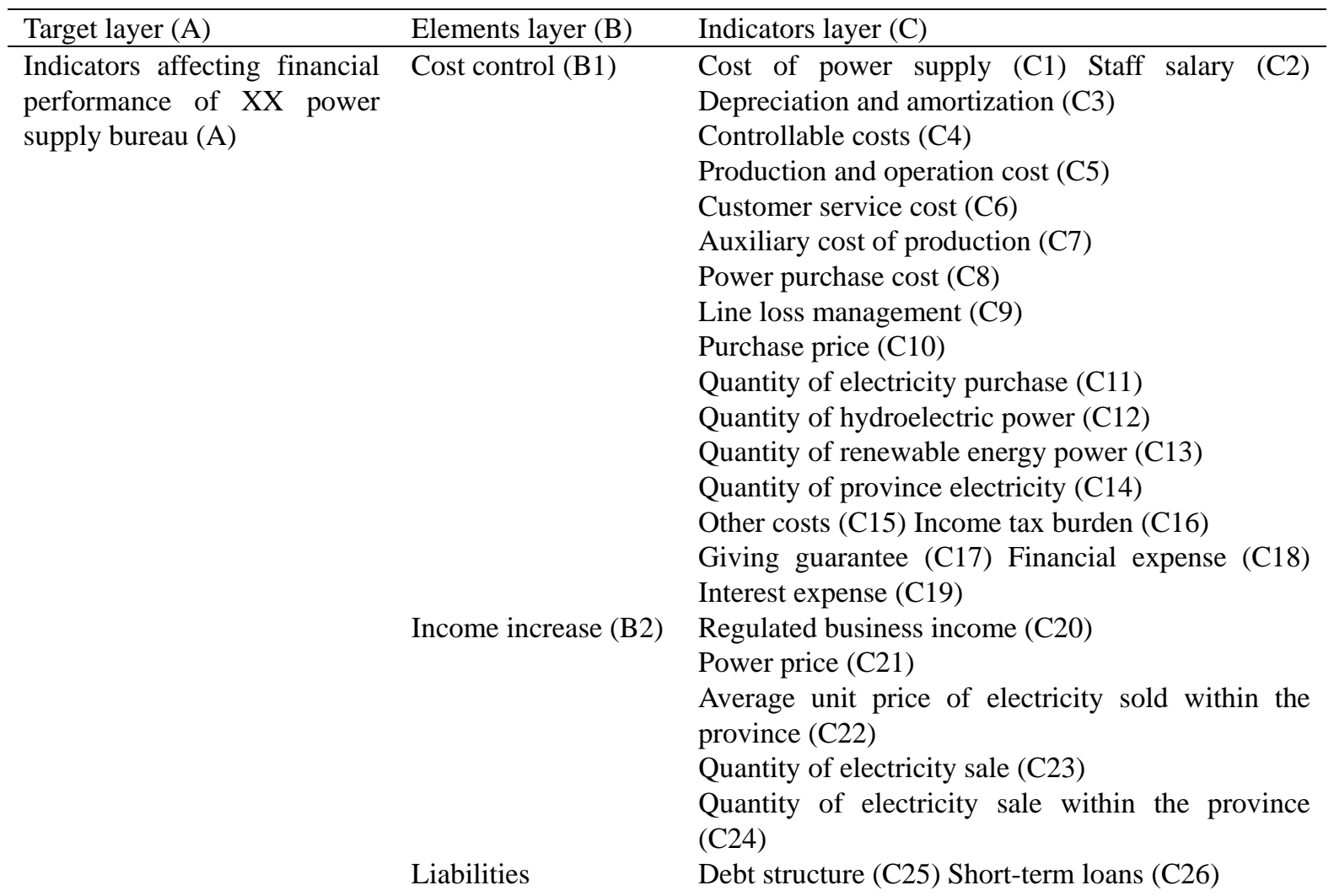


to optimize (B3)
Assets strengthen (B4)
Medium and long-term loans (C27)

Current assets (C28) Monetary fund (C29)

Power charge receivable (C30) Inventories (C31)

Engineering materials (C32)

Intangible assets (C33) Land (C34)

Investment of informatization (C35)

Fixed assets (C36)

Assets received (C37)

Community customer assets (C38)

Power grid investment (C39)

Marketing technology reform (C40)

Production technology reform (C41)

Small infrastructure (C42)

Main grid project (C43)

Distribution grid project (C44)

Asset retirement (C45)

\subsection{Questionnaire Design and Research}

This paper uses the financial performance indicators identified above as the evaluation object, and use the 6-point Likert scale to design the questionnaire, where 1 means "Not at all", 2 means "Not important”, and 3 means "Not too much”, 4 means " Important", 5 means " More important" and 6 means "Very important". When filling out the questionnaire, the internal employees of the company can rely on their own work experience to score the importance of the optimization of each indicator to the company's goal of achieving "first-class" financial management. The financial performance of each indicator is calculated by the internal financial management personnel to provide us with the target value. The questionnaire was conducted by the internal staff of the grid company, and the research time was in the second half of 2018.and actual value of the corresponding financial indicators for the year. In this study, 52 employees were surveyed, 52 questionnaires were retrieved, and invalid questionnaires (at least one unanswered or obviously inconsistent questionnaire) were screened out and 52 valid questionnaires were obtained. The effective questionnaire recovery rate for this survey is $100 \%$.

\section{IPA Model Example Application}

\subsection{Questionnaire Reliability Analysis}

Reliability analysis is mainly used to evaluate the stability or reliability of the questionnaire. The current method of reliability measurement commonly used in academia is the Cronbach's alpha coefficient method founded in 1951 by Cronbah. This paper uses SPSS21.0 software to make a reliability analysis of the data results of the overall item based on the results of the questionnaire survey. The reliability measure shows a reliability Cronbach's $\alpha$ coefficient of 0.697, which is higher than the minimum acceptable limit of 0.6. It shows that the evaluation indicators used in this study are of good reliability and can be used for further data analysis and application. 
Table 2. Reliability statistics

\begin{tabular}{ll}
\hline Cronbach's Alpha & Items \\
\hline .697 & 49 \\
\hline
\end{tabular}

\subsection{XX Power Supply Bureau Financial Indicator Elements IPA Model Results}

According to the results of the survey, the values calculated for all financial indicator elements are shown in the following table:

Table 3. The importance of financial indicators and the degree of performance completion

\begin{tabular}{|c|c|c|c|c|c|}
\hline Indicator & $\begin{array}{l}\text { Mean of } \\
\text { importance }\end{array}$ & $\begin{array}{l}\text { Degree of } \\
\text { performance } \\
\text { completion }\end{array}$ & Indicator & $\begin{array}{l}\text { Mean of } \\
\text { importance }\end{array}$ & $\begin{array}{l}\text { Degree } \\
\text { performance } \\
\text { completion }\end{array}$ \\
\hline $\begin{array}{l}\text { B1 } \\
\text { Cost control }\end{array}$ & 0.9808 & 1.0183 & $\begin{array}{l}\text { C22 Average unit price of } \\
\text { electricity sold within the } \\
\text { province }\end{array}$ & 1.0000 & 1.0165 \\
\hline $\begin{array}{l}\text { B2 } \\
\text { Income increase }\end{array}$ & 0.9872 & 0.9963 & $\begin{array}{l}\text { C23 Quantity of electricity } \\
\text { sale }\end{array}$ & 1.0000 & 0.9762 \\
\hline $\begin{array}{l}\text { B3 Liabilities to } \\
\text { optimize }\end{array}$ & 0.8389 & 1.0000 & $\begin{array}{l}\text { C24 Quantity of electricity } \\
\text { sale within the province }\end{array}$ & 1.0000 & 0.9762 \\
\hline $\begin{array}{l}\text { B4 } \\
\text { Assets strengthen }\end{array}$ & 1.0000 & 0.9796 & C25 Debt structure & 0.6346 & 1.0000 \\
\hline $\begin{array}{l}\text { C1 Cost of power } \\
\text { supply }\end{array}$ & 0.9808 & 1.0750 & C26 Short-term loans & 0.7051 & 1.0000 \\
\hline C2 Staff salary & 0.9135 & 1.0679 & $\begin{array}{l}\text { C27 Medium and } \\
\text { long-term loans }\end{array}$ & 0.7051 & 1.0000 \\
\hline $\begin{array}{l}\text { C3 Depreciation } \\
\text { and amortization }\end{array}$ & 0.8526 & 0.9830 & C28 Current assets & 0.7724 & 0.9659 \\
\hline $\begin{array}{l}\text { C4 } \\
\text { Controllable costs }\end{array}$ & 0.9712 & 1.1623 & C29 Monetary fund & 0.9968 & 0.9325 \\
\hline $\begin{array}{l}\text { C5 } \\
\text { Production } \\
\text { and operation cost }\end{array}$ & 0.9103 & 1.1880 & C30 Power charge receivable & 0.9679 & 0.9434 \\
\hline $\begin{array}{l}\text { C6 Customer } \\
\text { service cost }\end{array}$ & 0.7821 & 1.2412 & C31 Inventories & 0.8814 & 1.0000 \\
\hline $\begin{array}{l}\text { C7 Auxiliary cost } \\
\text { of production }\end{array}$ & 0.7724 & 1.0523 & C32 Engineering materials & 0.7340 & 1.0000 \\
\hline $\begin{array}{l}\text { C8 } \\
\text { Power purchase } \\
\text { cost }\end{array}$ & 0.9519 & 0.9829 & C33 Intangible assets & 0.8846 & 0.9863 \\
\hline $\begin{array}{l}\text { C9 Line loss } \\
\text { management }\end{array}$ & 0.9904 & 1.0171 & C34 Land & 0.9455 & 1.0000 \\
\hline $\begin{array}{l}\text { C10 } \\
\text { Purchase price }\end{array}$ & 0.8974 & 0.9189 & $\begin{array}{l}\text { C35 Investment } \\
\text { of informatization }\end{array}$ & 0.8878 & 0.9718 \\
\hline $\begin{array}{l}\text { C11 Quantity of } \\
\text { electricity } \\
\text { purchase }\end{array}$ & 0.9359 & 1.0081 & C36 Fixed assets & 0.9904 & 0.9842 \\
\hline $\begin{array}{l}\text { C12 Quantity of } \\
\text { hydroelectric } \\
\text { power }\end{array}$ & 0.6186 & 1.0457 & C37 Assets received & 0.8237 & 0.9286 \\
\hline $\begin{array}{l}\text { C13 Quantity of } \\
\text { renewable energy }\end{array}$ & 0.5673 & 1.0283 & $\begin{array}{l}\text { C38 Community customer } \\
\text { assets }\end{array}$ & 0.8686 & 0.9286 \\
\hline
\end{tabular}


power

0.9734

C39 Power grid investment

1.0000

0.9533

province

electricity

C15 Other costs $\quad 0.6763 \quad 0.986$

C40 Marketing technology

0.9423

0.9621

C16 Income tax $0.6282 \quad 1.0000$ reform

\section{burden}

C17

$0.7628 \quad 1.0000$

C41 Production technology 0.9423

0.8681 reform

Giving guarantee

C18

$0.7436 \quad 0.9601$

C42 Small infrastructure

0.9071

0.9639

Financial expense

$\begin{array}{llll}\text { C19 Interest } & 0.7564 & 0.9601\end{array}$

C43 Main grid project

1.0000

0.9877

expense

C20 Regulated $1.0000 \quad 0.9963$

C44 Distribution grid project

1.0000

0.9813

business income

C45 Asset retirement

0.7949

1.0000

C21 Power price

1.0000

1.0165

Through the importance level and performance completion of each indicator element in 2017, we can draw the IPA analysis matrix. For the importance of the indicator elements, we decided to calculate the value of 0.8756 by spss 21 based on the overall average of all indicator elements. For the performance completion degree, we take 1 as the baseline (the reference line is set as 1 , which is helpful to judge whether this indicator meets the performance target requirements of the enterprise, that is, whether it meets the actual value $=$ the target value). The IPA results of the financial data indicator layer of XX power supply bureau in 2017 are shown in the figure below.

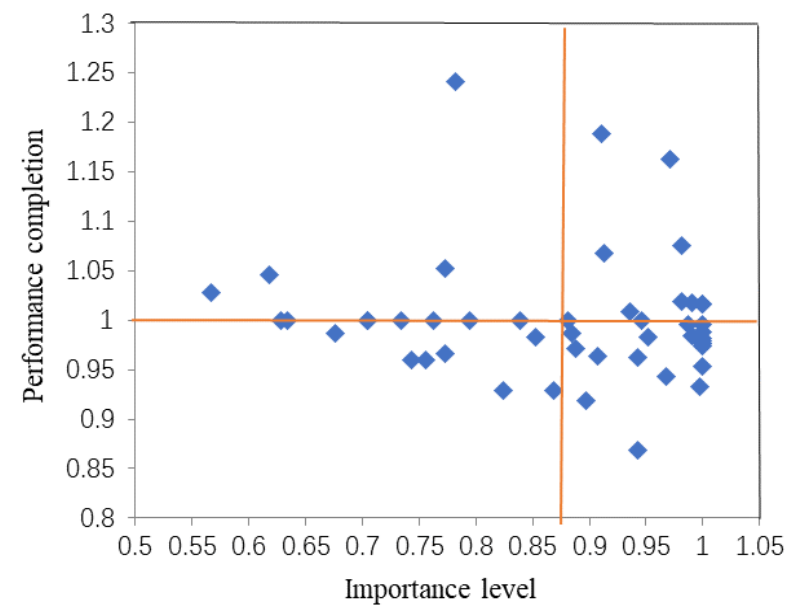

Figure 2. Figure IPA of financial indicators of XX power supply bureau in 2017

The indicators elements in the four partitions of IPA matrix are statistically analyzed, and the results are shown in the following table.

Table 4. 2017 XX power supply bureau financial indicators IPA model partition

\begin{tabular}{cc}
\hline Year & 2017 \\
\hline Area A & B1 Cost control C1 Cost of power supply C2 Staff salary C4 Controllable costs \\
& C5 Production and operation cost C9 Line loss management
\end{tabular}


C11 Quantity of electricity purchase C21 Power price

C22 Average unit price of electricity sold within the province

C31 Inventories C34 Land

Area B B3 Liabilities to optimize C6 Customer service cost C7 Auxiliary cost of production C12 Quantity of hydroelectric power C13 Quantity of renewable energy power

C25 Debt structure C26 Short-term loans C27 Medium and long-term loans

C32 Engineering materials

Area C C3 Depreciation and amortization C15 Other costs

C16 Income tax burden C17 Giving guarantee C18 Financial expense

C19 Interest expense C28 Current assets C37 Assets received

C38 Community customer assets C45 Asset retirement

Area D B2 Income increase B4 Assets strengthen C8 Power purchase cost

C10 Purchase price C14 Quantity of province electricity

C20 Regulated business income C23 Quantity of electricity sale

C24 Quantity of electricity sale within the province C29 Monetary fund

C30 Power charge receivable C33 Intangible assets

C35 Investment of informatization C36 Fixed assets

C40 Marketing technology reform C41 Production technology reform

C42 Small infrastructure C43 Main grid project C44 Distribution grid project

Area A (Advantages): B1 Cost control C1 Cost of power supply C2 Staff salary

C4 Controllable costs C5 Production and operation cost

C9 Line loss management C11 Quantity of electricity purchase

C21 Power price

C22 Average unit price of electricity sold within the province

C31 Inventories C34 Land

These indicators belong to high-importance and high-performance indicators, which are superior indicators of enterprise management and need to be maintained.

Area B (Maintenance): B3 Liabilities to optimize C6 Customer service cost

C7 Auxiliary cost of production

C12 Quantity of hydroelectric power

C13 Quantity of renewable energy power C25 Debt structure

C26 Short-term loans C27 Medium and long-term loans

C32 Engineering materials

The actual value of these indicators is equal to the target value set by the enterprise. At 
present, they have reached the performance requirements, but their importance is relatively low. Therefore, these are indicators that enterprises need to continue to consolidate.

Area C (Improvement): C3 Depreciation and amortization C15 Other costs

C16 Income tax burden C17 Giving guarantee

C18 Financial expense C19 Interest expense C28 Current assets

C37 Assets received C38 Community customer assets

C45 Asset retirement

The performance completion value of these indicators is less than 1 , indicating that these indicators have not yet reached the performance requirements of enterprises, but the importance of these indicators is not high. Therefore, these are indicators that enterprises should gradually improve.

Area D (Weakness): B2 Income increase B4 Assets strengthen C8 Power purchase cost

C10 Purchase price C14 Quantity of province electricity

C20 Regulated business income C23 Quantity of electricity sale

C24 Quantity of electricity sale within the province C29 Monetary fund

C30 Power charge receivable C33 Intangible assets

C35 Investment of informatization C36 Fixed assets

C40 Marketing technology reform C41 Production technology reform

C42 Small infrastructure C43 Main grid project

C44 Distribution grid project

The performance completion of these indicators is less than 1 , and the performance requirements of the enterprises have not yet been completed, and they are indicators of high importance and low performance. Therefore, these are weak indicators that enterprises should focus on strengthening.

\subsection{Summary}

In general, according to the analysis results of the IPA model of the financial indicators of XX power supply bureau, we can see that the main subjects that XX power supply bureau needs to break through at present are cost, income and assets. In terms of cost, enterprises should reduce power purchase cost and purchase price, reduce cost and improve management level. In terms of income performance, the enterprise should improve the quantity of electricity sale and quantity of electricity sale within the province, expand the regulated business income, collect power charge receivable, and then increase the enterprise income. As far as assets are concerned, the company's current assets, fixed assets and intangible assets are all goals that 
the company needs to improve at present. Enterprises should consider increasing monetary funds and improving their current assets. While fixed assets belong to the weak areas of enterprises, enterprises should increase their efforts to strengthen the fixed assets of enterprises from the aspects of marketing technology reform, production technology reform, main grid projects and distribution grid projects. As for the debt structure, enterprises mainly need to maintain the debt structure of enterprises and arrange the distribution of corporate debts reasonably.

\section{Case Revelation}

Based on the case analysis of the IPA model of the financial indicators of the XX power supply bureau, the financial enterprise performance evaluation system of the power enterprise is established. And provide the following suggestions for the objective problems of the company's weakest assets, providing a useful reference for the power industry to improve financial performance.

Judging from the IPA matrix of the assets related indicators of the XX power supply bureau, the main work of the enterprise to strengthen asset management is to manage fixed assets, covering physical and value management. In the process of asset management, there are problems in marketing technology reform, production technology reform, etc., and the physical management of assets and value management cannot be effectively linked. To improve the efficiency of enterprise asset management, the key is to improve the awareness of asset life cycle management and improve the technical means of asset management.

Improve asset lifecycle management. In the whole process of asset management, the lack of consideration in the initial planning will inevitably lead to post-management deficiencies, which makes it difficult to make up for. Therefore, it is required to strengthen comprehensive considerations in terms of safety, efficiency and cost in the initial stage of asset planning, strengthen initial investment management, ensure the safe and efficient operation of the company's assets while gradually reducing the life cycle cost, and gradually improve the current asset operation management. In the operation and maintenance phase, the company can operate the business for different types of maintenance, establish a scientific and reasonable standard operating library that meets the actual management, and quantify and determine the cost of each standard operating library. Establish methods and tools for job-based compilation standards, execution controls, and variance analysis by combining standard work libraries and standard costs with budget management. For asset transformation, according to the transformation objectives and principles, choose a reasonable transformation technology to carry out the work. In the retirement phase of asset retirement, asset life is divided into three categories, namely physical life, economic life and technical life. At this stage, grid companies need to analyze the relationship between various life types and system reliability to further understand the reasons why equipment needs to be decommissioned. For the difference between the possible existence and the design life, the company should also pay attention to the analysis. For the reason that the equipment must undergo early technical reform, it is necessary to trace back the reasons and strengthen the assessment. For returning 
equipment with good health, the inventory period should be reduced and reused as soon as possible. The company must take more measures and gradually extend the actual service life of the equipment to make the best use of it.

Optimize the linkage system between assets and equipment. The safety and reliability of power grid operation and power distribution are inseparable from the safety and reliability of power grid equipment. Under the background of transmission and distribution price reform, asset management is more important to the development of enterprise management. Strengthening the coordination of asset value management and equipment management is the key point for grid enterprises to carry out asset management. The linkage management of assets and equipment is the core management issue of power grid enterprises. It is not only related to the current basic management of power grid enterprises, but also related to the implementation of the company's overall strategy in the future. At present, the main network project and the distribution network project are all weak areas of the enterprise. Therefore, it is necessary for the enterprise to further optimize the linkage system of assets and equipment, improve the technical means of asset management, and pay attention to the material management work in the early stage of the project. A complete asset and equipment linkage information system platform needs to meet the following three requirements:

(1) System integration. Assets and equipment management should be tightly integrated.

(2) Scientific equipment system. There should be a set of scientific equipment management logic system.

(3) Smooth business processes. It should conform to the normal business process trend of the enterprise and realize the positive matching of information flow and business flow.

Above are the related suggestions of power enterprise asset management. The evaluation method of financial performance indicator of power grid enterprises constructed in this paper, IPA model, can be applied to the actual financial planning process in work and help enterprises optimize allocation of enterprise resources more efficiently. This model is applicable to the related general power supply enterprises, and has a certain scientific, systematic and practical nature, thus making the financial operation and management of enterprises more convenient and efficient. Gradually making the financial construction of the whole network and resource allocation come into a more precise era.

\section{References}

Chen, S. Q., Du, W. L., Zheng, C. N., \& Kang, L. F. (2011). Study on the performance evaluation system of grid enterprises. Friends of Accounting, (11), 97-101.

Evans, M. R., \& Chon, K. S. (1989). Formulating and evaluating tourism policy using importance-performance analysis. Hospitality Education and Research Journal, 13(3), 203-213.

Go, F. M., \& Zhang, W. (1997). Applying importance-performance analysis to Beijing as an 
international meeting destination. Journal of Travel Research, 35(4), 42-49.

Hawes, J. M., \& Rao, C. P. (1985). Using importance-performance analysis to develop health care marketing strategies. Journal of Applied Business Research, 10(4), 24-34.

Hsu, C. H., Byun. S., \& Yang, I. S. (1998). Attitudes of Korean college students towards quick-service, family-style, and fine dining restaurants. Journal of Restaurant \& Foodservice Marketing, 2(4), 65-85.

Jiang, P., \& Liu, G. D. (2018). Key factors in the development of green logistics -- empirical research based on Liaoning province. Ecological Economy, 34(07), 137-142, 161.

Lin, Z. (2011). Research on performance evaluation system of power grid enterprises--application of balance score card. Friends of Accounting, (11), 106-109.

Liu, X. (2011). Research on performance evaluation system of power grid enterprises. Friends of Accounting, (16), 103-106.

Martilla, J. A., \& James. J. C. (1977). Importance-performance analysis. Journal of Marketing, 41(1), 77-79.

Tang, D. N. (2017). Study on the influence mechanism of financial operation performance of power grid enterprises. Times Finance, (6), 116.

Zeng, D. J., \& Bao, Z. F. (2018). Diagnosis and improvement of higher vocational courses based on IPA model. Vocational Technology, 17(9), 75-80.

Zhao, H. M., \& Zhan, J. Q. (2008). Research on the evaluation method of operating performance of listed companies based on EVA. Vake Engineering, (8), 137-140.

\section{Copyright}

Copyright for this article is retained by the author(s), with first publication rights granted to the journal.

This is an open-access article distributed under the terms and conditions of the Creative Commons Attribution license (http://creativecommons.org/licenses/by/4.0/). 